\title{
Mechanism of prostaglandin F-2 $\alpha$ penetration from the horn of the uterus to the ovaries in pigs
}

\author{
J. Kotwica \\ Institute of Animal Physiology and Biochemistry, Academy of Agriculture and Technology, \\ 10-718 Olsztyn, Poland
}

\begin{abstract}
Summary. On Day 14 of the oestrous cycle PGF-2 $\alpha$ was infused into one anterior uterine vein $(15$ or $7.5 \mu \mathrm{g} / \mathrm{kg}$ body weight) or jugular vein $(15 \mu \mathrm{g} / \mathrm{kg})$ of pigs for $5 \mathrm{~h}$. Progesterone levels were significantly decreased in the ipsilateral and contralateral utero-ovarian veins, the effect being greater on the side of infusion and with the higher dose. Infusion into the jugular vein did not cause luteolysis. It is suggested that the lymphatic circulation may be involved in the passage of PGF- $2 \alpha$ from one uterine horn to the contralateral ovary.
\end{abstract}

\section{Introduction}

The time of survival of corpora lutea in the ipsilateral ovary is controlled by the uterine horn in sheep (Inskeep \& Butcher, 1966; Thorburn \& Nicol, 1971; McCracken et al., 1972), guinea-pigs (Bland \& Donovan, 1966; Fischer, 1967) and cows (Ginther, Woody, Mahajan, Janakiraman \& Casida, 1966). In pigs, however bilateral regression occurs after semihysterectomy (Spies, Zimmerman, Self \& Casida, 1958), although if as little as one-quarter of one horn is left intact, the corpora lutea on the opposite side do not regress (du Mesnil du Buisson, 1961). Krzymowski, Kotwica, Okrasa, Doboszyńska \& Zieçik (1978) reported that when prostaglandin (PG) F-2 $\alpha$ was infused into the anterior uterine vein the corpora lutea in the contralateral ovary also regressed. The corpora lutea in the opposite ovary contained smaller amounts of cAMP and histologically appeared to show more fatty degeneration than did the control ovaries. It was concluded that these changes were due to the arrival of PGF- $2 \alpha$ at the contralateral ovary in amounts sufficient to induce regression.

In the present study the progesterone content was investigated in the utero-ovarian veins of both uterine horns in pigs, during infusion of various PGF-2 $\alpha$ doses into the anterior uterine vein, and of higher doses into the jugular vein.

\section{Materials and Methods}

Pigs of the Polish Large White breed were used. They weighed $150 \mathrm{~kg}$ after pregnancy. On the 11 th day of the cycle (first symptoms of oestrus assumed as Day 0), 4 cannulae were surgically inserted as previously described (Krzymowski et al., 1978; Kotwica, Krzymowski \& Dębek, 1978): (1) into the jugular vein through the vena cephalica humeri; (2) into the anterior uterine vein of the right horn for infusion of PGF-2 $\alpha$ or saline; ( 3 and 4 ) into utero-ovarian veins for taking samples of blood flowing from the ovaries.

On Day 14 PGF-2 $\alpha$ (Tham salt) in $100 \mathrm{ml}$ saline $(9 \mathrm{~g} \mathrm{NaCl} / \mathrm{l})$ or $100 \mathrm{ml}$ saline were given during a 5-h infusion. The experimental groups were as follows: Group I received $15 \mu \mathrm{g}$ PGF- $2 \alpha / \mathrm{kg}$ body weight into the anterior uterine vein, Group II received $7.5 \mu \mathrm{PGF}-2 \alpha / \mathrm{kg}$ into 
the anterior uterine vein, Group III sows were infused with $100 \mathrm{ml}$ saline into the anterior uterine vein and Group IV sows received $15 \mu \mathrm{g}$ PGF-2 $\alpha$ into the jugular vein. Blood samples were withdrawn from cannulae 1,3 and 4, three times before starting the infusion and at 15-min intervals throughout infusion. The samples were heparinized ( $100 \mathrm{i} . \mathrm{u} . / 4 \mathrm{ml}$ blood), and the blood was immediately centrifuged. The plasma was frozen and stored at $-20^{\circ} \mathrm{C}$. The experiment was carried out during the period from winter to spring 1977-1978 successively with the Groups I, II, III and IV.

\section{Progesterone assay}

Progesterone concentrations were determined by the protein-binding technique (Johansson, 1970) with the modifications described earlier by Krzymowski et al. (1978). The sensitivity of the method was expressed as the value of two standard deviations for zero samples: $93.7 \%$ differed statistically significantly from the zero sample, i.e. $100 \%(n=32)$. The intra- and inter-assay variations were $5.09 \%$ for 22 pairs of determinations and $8.59 \%$ for 17 pairs of determinations, respectively. The mean \pm s.e.m. extraction yield from a randomly chosen combination $(n=21)$ was $85.8 \pm 3 \cdot 1 \%$. A linear equation, $y=0 \cdot 161+0.994 x$, was calculated from determinations of known amounts of $2(n=5), 5(n=5), 10(n=6), 50(n=6), 100$ $(n=4)$ and $200 \mathrm{ng}(n=7)$ progesterone added to the plasma of bilaterally ovariectomized and hysterectomized pigs.

\section{Statistical analysis}

The statistical significance of differences between the mean values was established by Student's $t$ test.

\section{Results}

The results are shown in Table 1 . These data show that the ovary adjacent to the site of infusion of PGF-2 $\alpha$ releases less progesterone in the 5 th hour of infusion, the reduction depending on the dose of PGF-2 $\alpha$ administered. Progesterone concentrations in the blood from the contralateral ovary were also reduced significantly in Group I but not so greatly.

Table 1. Plasma progesterone concentrations (mean \pm s.e.m.) in pigs before and after infusion of saline (Group III) or PGF-2 $\alpha$ in the anterior uterine vein (Groups I and II) or into the jugular vein (Group IV)

\begin{tabular}{|c|c|c|c|c|c|c|c|c|c|c|c|c|}
\hline & \multicolumn{3}{|c|}{ Group I $(N=4)$} & \multicolumn{3}{|c|}{ Group II $(N=4)$} & \multicolumn{3}{|c|}{ Group III $(N=6)$} & \multicolumn{3}{|c|}{ Group IV $(N=4)$} \\
\hline & $0 \mathrm{~h}$ & $5 \mathrm{~h}$ & $\begin{array}{c}\% \\
\text { change }\end{array}$ & $0 \mathrm{~h}$ & $5 \mathrm{~h}$ & $\begin{array}{c}\% \\
\text { change }\end{array}$ & $\mathrm{Oh}$ & $5 \mathrm{~h}$ & $\begin{array}{c}\% \\
\text { change }\end{array}$ & $\mathrm{Oh}$ & $5 \mathrm{~h}$ & $\begin{array}{c}\% \\
\text { change }\end{array}$ \\
\hline $\begin{array}{l}\text { Utero-ovarian vei } \\
\text { Ipsilateral }\end{array}$ & $\begin{array}{l}270.28 \\
\pm 68.23\end{array}$ & $\begin{array}{l}78 \cdot 15 \\
\pm 5.19 \dagger\end{array}$ & 71.1 & $\begin{array}{l}211.92 \\
\pm 39.61\end{array}$ & $\begin{array}{l}102.42 \\
\pm 24.00^{*}\end{array}$ & 51.7 & $\begin{array}{l}120.68 \\
\pm 14.53\end{array}$ & $\begin{array}{l}134.78 \\
\pm 6.82\end{array}$ & 11.7 & $\begin{array}{l}59.41 \\
\pm 20.90\end{array}$ & $\begin{array}{l}57.52 \\
\pm 13.75\end{array}$ & $3 \cdot 2$ \\
\hline Contralateral & $\begin{array}{l}150.92 \\
\pm 28.54\end{array}$ & $\begin{array}{l}76.44 \\
\pm 13.62^{*}\end{array}$ & 49.4 & $\begin{array}{l}171 \cdot 16 \\
\pm 35 \cdot 16\end{array}$ & $\begin{array}{r}136.40 \\
\pm 5.81\end{array}$ & $20 \cdot 3$ & $\begin{array}{r}75.89 \\
\pm 10.73\end{array}$ & $\begin{array}{r}82.56 \\
\pm 15.37\end{array}$ & 8.7 & & & \\
\hline Jugular vein & $\begin{array}{r}16.77 \\
\pm 1.17\end{array}$ & $\begin{array}{l}9.29 \\
\pm 0.77 \ddagger\end{array}$ & $44 \cdot 7$ & $\begin{array}{r}11.68 \\
\pm 1.38\end{array}$ & $\begin{aligned} & 6.37 \\
\pm & 0.44 \dagger\end{aligned}$ & $45 \cdot 5$ & $\begin{array}{r}16.27 \\
\pm 0.93\end{array}$ & $\begin{array}{r}20.47 \\
\pm 3.26\end{array}$ & $25 \cdot 3$ & $\begin{array}{l}10.53 \\
\pm 2.74\end{array}$ & $\begin{array}{l}13.35 \\
\pm 2.62\end{array}$ & 26.7 \\
\hline
\end{tabular}

Values significantly different from that at $0 \mathrm{~h}:{ }^{*} P<0.05, \dagger P<0.01, \ddagger P<0.001$.

The progesterone level in peripheral blood is the resultant of the changes in both ovaries. Although there was unchanged concentration of peripheral plasma progesterone in Group III (controls), the values in Group I and II decreased significantly and to a similar proportional extent. 
When PGF-2 $\alpha$ was administered via the jugular vein (Group IV), progesterone concentrations in the utero-ovarian vein and in the peripheral circulation did not differ.

The changes observed with time are illustrated in Text-fig. 1. A significant fall of progesterone level was recorded as early as 90 min after the start of infusion in Groups I and II.

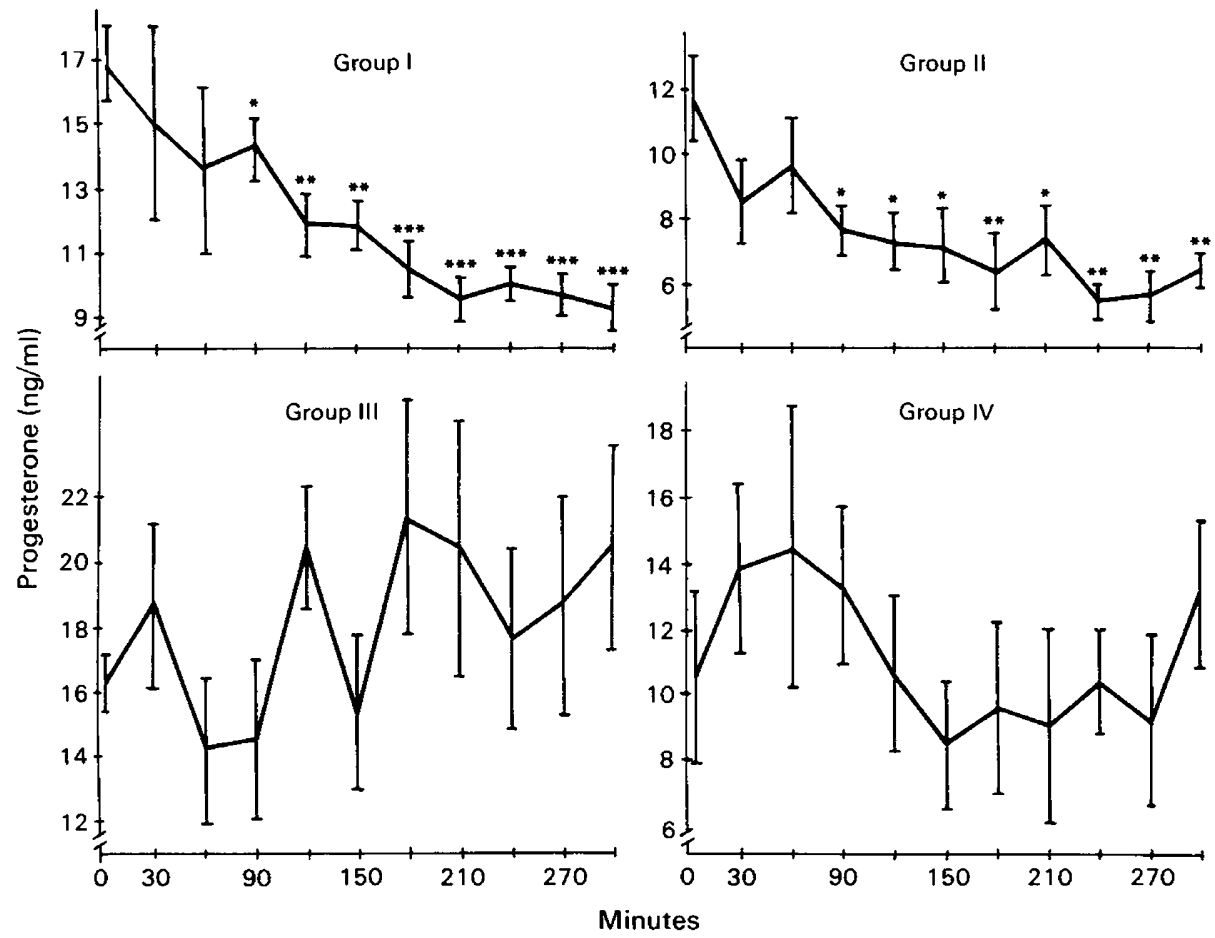

Text-fig. 1. Peripheral plasma progesterone concentrations in pigs infused with saline (Group III) or PGF-2 $\alpha$ into the anterior uterine vein (Group I, $15 \mu \mathrm{g} / \mathrm{kg}$; Group II, $7.5 \mu \mathrm{g} / \mathrm{kg}$ ) or into the jugular vein $(15 \mu \mathrm{g} / \mathrm{kg})$. Values are mean \pm s.e.m. and those significantly different from the value at $0 \mathrm{~h}$ are indicated: ${ }^{*} P<0.05 ;{ }^{* *} P<0.01 ;{ }^{* * *} P<0.001$.

\section{Discussion}

Peripheral progesterone concentrations before infusion were surprisingly lower in Groups II and IV than in Groups I and III, perhaps due to a seasonal effect as shown by Rosenberg, Herz, Davidson \& Folman (1977) for cows which have higher progesterone levels in winter. However, the within group comparisons in the present study indicate that PGF-2 $\alpha$ can pass from the uterine vein to the ovary in pigs, since progesterone secretion was decreased in the ovary ipsilateral to the site of PGF-2 $\alpha$ infusion when that was the utero-ovarian vein. This suggests that PGF- $2 \alpha$ originating from the endometrium is probably indispensable for eliciting luteal regression in pigs although the porcine corpus luteum is also known to produce some PGF-2 $\alpha$ (Patek \& Watson, 1976), as in women (Challis et al., 1976), cattle (Kuehl, Cirillo, Ham \& Humes, 1972) and rats (Demers, Behrman \& Greep, 1972). The pathway used, however, is unresolved. In sheep, PGF-2 $\alpha$ penetrates from the uterine vein to the ovarian artery (Barrett et al., 1971; McCracken et al., 1972). In pigs, however, the problem seems to be different: Harrison \& Heap (1972) excised the right ovary of a pig and transplanted in its place the left one. There was no vascular connection between the uterus and the transplanted ovary. The uterine vein was separated from 
the ovarian artery along a $5 \mathrm{~cm}$ segment, checked radiographically. Nevertheless, regular sexual cycles and normal pregnancies were observed. Anderson, Butcher \& Melampy (1963) surgically detached the uterine horns from the broad ligament between the anterior part of the oviduct and the cervix uteri. In 4 of 9 pigs symptoms of oestrus appeared at 22-28-day intervals and the uterine endometrium remained active.

In the present experiment PGF-2 $\alpha$ infused into the anterior uterine vein also caused regressive changes in the contralateral ovary. Patek \& Watson (1976) suggest that although the corpora lutea are controlled by PGF- $2 \alpha$ produced in the uterus, such PGF- $2 \alpha$ stimulates the corpora lutea to release their own PGF- $2 \alpha$ which then acts to induce regression. This supposition does not, however, explain how PGF-2 $\alpha$ penetrates from the uterus to the ovary or from the uterine horn to the opposite ovary. A partial answer to this question may be found in the results obtained with the Group IV pigs. The lack of effect of PGF-2 $\alpha$ infusion into the jugular vein indicates that PGF-2 $\alpha$ cannot be passing to the opposite ovary via the general circulation and that an extravascular pathway must be involved.

During the surgery for the present experiments rich lymphatic vascularization was observed in the uterus, as reported by Anderson, Bland \& Melampy (1969). In view of the size of the PGF-2 $\alpha$ molecule and its ability to migrate from endometrial cells into the capillary lumen or into the lumen of the uterine horn in various physiological states (Bazer \& Thatcher, 1977; Frank, Bazer, Thatcher \& Wilcox, 1978), it is possible that lymph is the means by which PGF-2 $\alpha$ is transported within the female reproductive system of pigs.

We thank Dr J. W. Lauderdale, Upjohn Co., Kalamazoo, Michigan, for the PGF-2 $\alpha$. This work was supported by the Institute of Pathology and Therapy of Animals, Academy of Agriculture, Wrockaw, as a part of a Research Project of the Ministry of Higher Education, Science and Technology MR.II.10.

\section{References}

Anderson, L.L., Butcher, R.L. \& Melampy, R.M. (1963) Uterus and occurrence of oestrus in pig. Nature, Lond. 198, 311-312.

Anderson, L.L., Bland, K.P. \& Melampy, R.M. (1969) Comparative aspects of uterine relationship. Recent Prog. Horm. Res. 25, 57-104.

Barrett, S., de Blockey, M.A., Brown, J.M., Cumming, S.A., Goding, J.A., Mole, B.J. \& Obst, J.M. (1971) Initiation of the oestrous cycle in the ewe by infusions of $\mathrm{PGF}_{2 a}$ into the autotransplanted ovary. J. Reprod. Fert. 24, 136-137.

Bazer, F.W. \& Thatcher, W.W. (1977) Theory of maternal recognition of pregnancy in swine based on estrogen controlled endocrine versus exocrine secretion of prostaglandin $F_{2 \alpha}$ by the uterine endometrium. Prostaglandins 14, 397-401.

Bland, K.P. \& Donovan, B.T. (1966) Asymmetry in luteal size following hemi-hysterectomy in the guinea pig. J. Endocr. 34, iii, Abstr.

Challis, J.R.G., Calder, A.A., Dilley, S., Forster, C.S., Hillier, K., Hunter, D.J.S., McKenzie, I.Z. \& Thorburn, G.D. (1976) Production of prostaglandins $E$ and $F_{\alpha}$ by corpora lutea, corpora albicantes and stroma of the human ovary. $J$. Endocr. 68, 401-408.

Demers, L.M., Behrman, H.R. \& Greep, R.O. (1972) Effects of prostaglandin and gonadotropin on luteal prostaglandin and steroid biosynthesis. Adv. Biosci. 9, 701-707. du Mesnil du Buisson, F. (1961) Regression unilaterale des corps jaunes après hysterectomie partielle chez le Truie. Annls Biol. anim. Biochim. Biophys. 1, 105-112.

Fischer, T.V. (1967) Local uterine regulation of the corpus luteum. Am. J. Anat. 121, 425-442.

Frank, M., Bazer, W.F., Thatcher, W.W. \& Wilcox, C.J. (1978) A study of prostaglandin $F_{2 \alpha}$ as a luteolysin in swine. IV. An explanation for the luteotropic effect of estradiol. Prostaglandins 15, 151-160.

Ginther, OJ., Woody, C.O., Mahajan, S., Janakiraman, K. \& Casida, L.E. (1966) Some effects of unilateral hysterectomy and oxytocin administration in heifers. J. Anim. Sci. 25, 923, Abstr.

Harrison, F.A. \& Heap, R.B. (1972) Ovarian activity in a pig after autotransplantation of an ovary. $J$. Physiol., Lond. 226, 39.

Inskeep, E.K. \& Butcher, R.L. (1966) Local component of utero-ovarian relationship in the ewe. J. Anim. Sci. 25, 1164-1168.

Johansson, E.D.P. (1970) A simplified procedure for the assay of progesterone. Acta endocr., Copenh., Suppl. 147, 188-203.

Kotwica, J., Krzymowski, T., \& Dȩbek, J. (1978) Kaniulizowanie naczyń żylnych u świń do badań endokrynologicznych. Med. Wet. 34, 118-120.

Krzymowski, T., Kotwica, J., Okrasa, S., Doboszyńska, T. \& Zieçik, A. (1978) Luteal function in sows after unilateral infusion of PGF-2 $\alpha$ into the anterior 
uterine vein on different days of the oestrous cycle. $J$. Reprod. Fert. 54, 21-27.

Kuch, F.A., Cirillo, V.J., Ham, E.A. \& Humes, J.L. (1972) The regulatory role of the prostaglandins on the cyclic 3',5'-AMP system. Adv. Biosci. 9, 155172.

McCracken, J.A., Carison, J.C., Glew, M.E., Goding, J.R., Baird, D.T., Green, K. \& Samuelsson, B. (1972) prostaglandin $F_{2 a}$ identified as a luteolytic hormone in sheep. Nature, New Biol. 238, 129-134.

Patek, Ch.E. \& Watson, J. (1976) Prostaglandin F and Progesterone secretion by porcine endometrium and corpus luteum in vitro. Prostaglandins 12,97-111.
Rosenberg, M., Herz, Z., Davidson, M. \& Folman, Y. (1977) Seasonal variations in post-partum plasma progesterone levels and conception in primiparous and multiparous dairy cows. J. Reprod. Fert. 51, 363-367.

Spies, H.G., Zimmerman, D.R. Self, H.L. \& Casida, L.E. (1958) Influence of hysterectomy and exogenous progesterone on the size and progesterone content of the corpora lutea in gilts. J. Anim. Sci. 17, 1234, Abstr.

Thorburn, G.D. \& Nicol, D.H. (1971) Regression of the ovine corpus luteum after infusion of prostaglandin $F_{2 a}$ into the ovarian artery and uterine vein. $J$. Endocr. 51, 785-786.

Received 28 November 1979 